\title{
The Impact of COVID-19 on Library Users
}

\section{Rosalind "Rose" Derksen"}

${ }^{1}$ School of Library and Information Studies, University of Alberta, rderksen@ualberta.ca

To Cite:

Derksen, R. (2021). The impact of COVID-19 on library users. Pathfinder: $A$

Canadian Journal for Information Science Students and Early Career Professionals. 2(2), 100-103. https://doi.org/10.29173/pathfinder35

\footnotetext{
Abstract

A reflection on how COVID-19 has affected library users, from the perspective of a first-year MLIS student.
}

Keywords: COVID-19, Library Use, Pandemic, Reflection, Digital Divide, MLIS

A

sk any MLIS-holder: obtaining a master's degree in Library and Information

Studies is a demanding experience, one that pushes students' limits and challenges their preconceptions. If you throw an unprecedented health crisis into the mix, a whole new layer of complexity is added. To survive and thrive in their studies, graduate students rely on libraries, and a global pandemic doesn't change that. The pandemic almost derailed my own ability to access library services, which would have sidelined my academic success and future career path.

Over the past year, librarians have done amazing work to make library services available virtually, even while physical library spaces have been locked down, and physical collections are inaccessible. As a result, the COVID-19 pandemic has effectively divided library users into two groups: those who are able to take advantage of virtual services, and those who rely on in-person facilities and services. Those in the former group have largely had their information needs met during the lockdown; in fact, they've seen an increase in resources available to them. Meanwhile, the latter have lost 
not only their access to information resources, but also the experience of community that libraries offer.

For users who are able to access virtual library services, the closure of physical library spaces has little or no impact on their information needs. Patrons who are able to take advantage of virtual services are aware that "it is really only the building that is closed for now ... e-resources are obviously still available, and access to these services requires ongoing effort and support by library staff" (Ayre \& Craner, 2020, p. 17). Some users even prefer virtual services. A few months into the pandemic, Brian Kenney, Director of White Plains Public Library in New York, observed:

We've ... ended up meeting so many residents who could never make it to our building for our programs because they were caring for kids or elderly parents, or had physical challenges or had other impediments. These patrons crowded into our Zoom workshops, joined online book groups, and are now able to participate in the community, all because we are finally meeting them where they are. (Kenney, 2020, p. 28)

For users whose information needs can be met virtually, increased digital resources means that the pandemic has actually enriched their library-use experience.

However, for users who rely on in-person library services, the lockdown has obstructed access, not only to information resources, but also to an important community hub. Seattle Public Library Executive Director Marcellus Turner noted early in the lockdown, "Our city's most vulnerable communities ... seek warmth and safety, and they need information access too. [...] How we reach them and how we help them in moments like these is a concern" (Freudenberger, 2020, p. 4). Terry Kirchner, Executive Director of the Westchester Library System in New York, asked, "Where will our seniors who rely on libraries to provide social interaction go? What options will our patrons without home access to the internet have to stay connected?" (Freudenberger, 2020 , p. 6). In-person users have suffered a two-fold loss: loss of information access, and the less tangible loss of connection to and connectedness within the community.

COVID has also highlighted the digital divide among student library users, including graduate students like me. Danish researchers Jæger and Blaakæk published a study analyzing the learning opportunities of Danish students over several months of 
lockdown learning (Jæger \& Blaakæk, 2020), which revealed a direct correlation between students' learning opportunities and the quantity of digital materials they accessed through libraries. One significant finding is that the students who accessed the most digital library materials were also the most financially secure. Conversely, financially insecure students were severely disadvantaged as a result of the closure of physical library spaces, including both public and academic libraries.

As for myself, I was able to take advantage of virtual library services during the first year of my MLIS studies - but only because I received generous financial support. During my undergraduate studies, I relied very heavily on my local public and academic libraries, and on one small campus library in particular. At the time, I was in a financially precarious position, and I did not always have at-home internet access, or a quiet space to study at home. Unable to afford a good laptop or desktop, I nevertheless managed to get through a four-year degree with only a Chromebook, pencils and paper. As you can imagine, I needed the library not only for print and digital materials, but also for computer and equipment use, internet access, and a safe space. As I got to know the staff and other "regulars," the library became like a second home. I felt that I belonged in the library, and it became an important source of community in my life.

When I returned to university to pursue my MLIS in the middle of the pandemic, I knew I would not be able to return to my friendly campus library for support. The transition to online learning only increased student dependence on the internet and technology, and I quickly realized that without the help of the library, I would not be able to continue my studies, and I was faced with the prospect of having to withdraw from my program. It was only through student loans and the generosity of a friend that I was able to equip myself with a functional computer and printer, and at-home Wi-Fi. I found myself in the privileged position of having a dependable internet connection, equipment of my own, and a quiet apartment to work in, and a whole new world suddenly opened before me. I could access digital journal articles and eBooks for my studies, as well as music, movies, and audiobooks for entertainment. If I have questions, I can easily ask a librarian through the library website's chat feature. I'm even able to take part in initiatives like virtual book clubs and workshops, which helps to lessen the impact of being unable to access in-person community spaces. Financial support allowed me to 
continue my studies and stay connected to my community, and for that I am profoundly grateful - but I am still missing that "second home" feeling that comes from being physically present in a library, with its kind staff and welcoming community.

Starting my MLIS during lockdown has made me more acutely aware of how much I depend on libraries to succeed and achieve. I was able to have my library needs met virtually, but I recognize that there are many library users who do not have the same supports that I did. Because of the shutdown of physical library spaces and services, I came frighteningly close to being unable to pursue my education. As a future librarian, my experience during the pandemic has made me more resolved to be an advocate for more equitable access to library services for all patrons, and to strive to meet their information needs in whatever way is best for them, whether virtually or in person.

\section{Conflict of Interest Statement}

None declared.

\section{References}

Ayre, L., \& Craner, J. (2020). Libraries are open — only the buildings are closed. Collaborative Librarianship, 12(1), 14-19. https://digitalcommons.du.edu/collaborativelibrarianship/vol12/iss1/4

Freudenberger, E. (2020). Not business as usual. Library Journal, 145(4), 24-27. https://www.libraryjournal.com/?detailStory=not-business-as-usual-ala-midwinter2017

Jæger, M.M., \& Blaakæk, E.H. (2020). Inequality in learning opportunities during Covid19: evidence from library takeout. Research in Social Stratification and Mobility, 68, 1-5. https://doi.org/10.1016/j.rssm.2020.100524

Kenney, B. (2020, June 8). All by ourselves. Publishers Weekly. 267(23), 24-28. https://www.publishersweekly.com/pw/by-topic/industrynews/libraries/article/83523-all-by-ourselves.html 